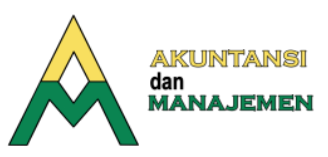

https://akuntansi.pnp.ac.id/jam

e-ISSN 2657-1080, p-ISSN 1858-3687

Akuntansi dan Manajemen

Vol. 16, No. 2, 2021, Hal. 227-248

\title{
Pengaruh Iklim Organisasi Dan Kepuasan Kerja Terhadap Kinerja Karyawan
}

\author{
Refli Renaldi' ${ }^{1}$, Imamul Khaira ${ }^{2}$ \\ ${ }^{1}$ Program Studi Manajemen, Universitas Haji Sumatera Utara \\ Email: reflirenaldi@gmail.com \\ 2Program Studi Manajemen, Universitas Haji Sumatera Utara \\ Email: imamulkhaira@gmail.com
}

\begin{abstract}
This study is to examine the influence: between atmosphere of the organization and employees' satisfaction against the employees' performance partially or simultaneously. The good atmosphere of the organization became more effective in increasing employees' work satisfaction; and finally obtain good employees' performance. This situation cannot be found in this company. This study used descriptive methode. All of employees became sample (36 people). The data was collected by observation, interview and questioner. The data were analyzed by using multiple regression analysis with F-test (simultaneous) and T-test (partial) at the significance level of 95\%. The result of the study provides a conclusion as follow: 1 . There is a significant influence between organization atmosphere against the employees' performance in PT. Yuri Cakra Brothers. (2) There is a significant influence between employees' satisfaction against the employees' performance in PT. Yuri Cakra Brothers, (3) There is a significant influence between organization atmosphere and employees' satisfaction altogether against employees' performance in PT. Yuri Cakra Brothers.
\end{abstract}

Keywords : Organisation Atmosphere, Employees Satisfaction and Employees Performance

\begin{abstract}
ABSTRAK
Penelitian ini bertujuan untuk mengetahui pengaruh antara Iklim Organisasi dan Kepuasan Kerja terhadap Kinerja Karyawan pada PT. Yuri Cakra Brothers secara bersama-sama maupun secara sendiri. Karyawan menginginkan iklim organisasi yang baik yang akan memberi kepuasan kerja; yang pada akhirnya menghasilkan kinerja yang baik. Kondisi ini belum dapat di temukan pada perusahaan ini. Penelitian ini menggunakan metode deskriptif dengan jumlah sampel sebanyak 36 orang (semua karyawan). Data dalam penelitian ini diperoleh dengan cara: observasi, wawancara dan kuesioner. Data dianalisa menggunakan Regresi Linear Berganda dengan F-test (simultan) dan T-test (parsial) dengan signifikansi 95\%. Kesimpulan pada penelitian ini adalah:1. Terdapat pengaruh yang signifikan antara Iklim Organisasi terhadap Kinerja Karyawan pada PT. Yuri Cakra Brothers. (2) Terdapat pengaruh yang signifikan antara Kepuasan Karyawan terhadap Kinerja Karyawan pada PT. Yuri Cakra Brothers, (3) Terdapat pengaruh yang signifikan antara Iklim Organisasi dan Kepuasan Karyawan secara bersama-sama terhadap Kinerja Karyawan pada PT. Yuri Cakra Brothers.
\end{abstract}

Kata Kunci : Iklim Organisasi, Kepuasan Kerja dan Kinerja Karyawan. 


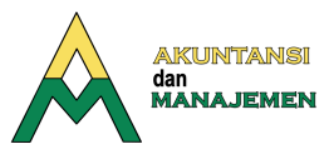

https://akuntansi.pnp.ac.id/jam

e-ISSN 2657-1080, p-ISSN 1858-3687

\section{Pendahuluan}

Persaingan dunia bisnis dalam era globalisasi saat ini menjadi semakin ketat. Manajemen Sumber Daya Manusia (MSDM) adalah bidang yang paling menarik dalam menyikapi persaingan bisnis di era globalisasi saat ini. Salah satu alasannya adalah dalam MSDM yang dikelola adalah manusia dengan segala keunikan dan kinerjanya. Manusia bukanlah mesin atau robot yang dapat dengan sistematik diprogram untuk bekerja mencapai tujuan sesuai dengan pola dan program yang telah dibuat terus sama mulai dari A sampai Z. Manusia mempunyai pikiran, hati, dan perasaan yang senantiasa berubah; manusia bersifat dinamis. Oleh karena itu diperlukan kelenturan dalam mengelola sumber daya manusia dengan bakatnya masing-masing dan seluruh potensi karyawan perlu dikembangkan untuk kemanfaatan dalam mencapai tujuan perusahaan. Hasibuan, beliau berpendapat Sumber Daya Manusia memiliki arti keahlian terpadu yang berasal dari daya pikir serta daya fisik yang dimiliki oleh setiap orang [17]. Yang melakukan serta sifatnya dilakukan masih memiliki hubungan yang erat seperti keturunan dan lingkungannya, sedangkan untuk prestasi kerjanya dimotivasi oleh sebuah keinginan dalam memenuhi keinginannya.

Tantangan MSDM akhir-akhir ini adalah globalisasi, di mana bisnis sudah tidak lagi mengenal batas Negara dan ideologi. MSDM sebagai software perusahaan atau unit bisnis perlu untuk memahami bisnis global dengan segala variannya. Di lingkup negara-negara ASEAN, pada tahun 2016 ini Indonesia sudah berkiprah di Asean Economics Community (AEC) atau Masyarakat Ekonomi Asean (MEA). Dalam MEA itu akan terbuka praktik ekonomi bebas di 10 Negara Asean. Tidak akan dibenarkan lagi adanya pembatasan dagang atau bisnis antar negara. Keadaan ini menuntut setiap organisasi baik pemerintah maupun swasta agar lebih mampu beradaptasi, mempunyai ketahanan, melakukan perubahan arah dengan cepat dan harus senantiasa mengevaluasi dan memperbaiki praktek-praktek bisnis serta Iklim Organisasi. Iklim Organisasi merupakan status emosi yang ditunjukkan oleh setiap anggota sistem yang dapat berupa formal, rileks, defensive, berhati-hati, menerima, percaya, dan sebagainya. Pada dasarnya, Iklim Organisasi lebih menekankan pada pendeskripsian atmosfer organisasi dari pada mengevaluasi atau mengindikasikan reaksi emosional terhadap organisasi. Wirawan, menyatakan bahwa iklim organisasi adalah persepsi anggota organisasi (secara individual atau kelompok) dan mereka yang secara tetap berhubungan dengan organisasi mengenai apa yang ada atau terjadi dalam lingkungan internal organisasi secara rutin, yang mempengaruhi sikap dan perilaku organisasi dan kinerja anggota organisasi yang kemudian menentukan kinerja organisasi [33]. Pasaribu dan Indrawati, mengemukakan pendapat bahwa iklim organisasi merupakan kualitas lingkungan yang relatif dari organisasi yang dialami oleh anggotanya [24]. Hal itu memiliki efek pada perilaku mereka dan bagaimana organisasi tersebut berfungsi baik. Iklim organisasi dibedakan menjadi dua yaitu kondisi lingkungan organisasi yang menyangkut fisik dan kondisi lingkungan organisasi yang menyangkut psikis atau non-fisik. Subawa dan Surya, menyatakan bahwa iklim organisasi sebagai persepsi seseorang terkait aspek pekerjaan dan nilainilai organisasinya [28], dengan demikian dinyatakan bahwa iklim organisasi 
merupakan suatu persepsi masing-masing individu mengenai karakteristik dan kondisi organisasi yang mempengaruhi perilaku seseorang dalam menjalani pekerjaan.

Richard, Robert dan Gordon menegaskan bahwa kepuasan kerja berhubungan dengan perasaan atau sikap seseorang mengenai pekerjaan itu sendiri, gaji, kesempatan promosi atau pendidikan, pengawasan, rekan kerja, beban kerja dan lainlain [25]. Dengan demikian karyawan menginginkan iklim kerja yang akan memberi mereka kepuasan kerja. Iklim organisasi yang kondusif tentunya mampu memberi Kepuasan Kerja bagi para karyawan dalam bekerja, bahkan kemungkinan mereka akan loyal dan berkomitmen pada organisasi. Setiap karyawan yang bekerja dalam sebuah organisasi memerlukan rasa aman, nyaman dan menyenangkan; yang kesemuanya itu dapat diperoleh dalam lingkungan organisasi yang memiliki Iklim Organisasi yang sehat kondusif. Keberadaan Iklim Organisasi yang sehat memungkinkan setiap karyawan untuk bekerja secara lebih baik, sehingga kelancaran tugasnya dapat tercapai dengan hasil yang maksimal. Organisasi diartikan sebagai suatu sistem yang terdiri dari subsistem-subsistem yang saling berkaitan (interdependence) satu sama lain dan dalam proses kerjasama untuk mencapai tujuan tertentu. Argote, dalam sebuah organisasi setiap proses interaksi antara suatu subsistem dengan subsistem lainnya tidak ada jaminan untuk senantiasa adanya kesesuaian antara individu [1]. Pada tataran pelaksananya, bisa saja muncul ketegangan baik antar individu maupun antar kelompok. Adapun faktor yang melatar belakangi munculnya ketidakcocokan atau ketegangan, sebagai berikut: (1) sifat-sifat pribadi yang berbeda, (2) perbedaan kepentingan, (3) komunikasi yang buruk, dan (4) perbedaan nilai. Perbedaan-perbedaan inilah yang akhirnya membawa organisasi ke dalam suasana konflik. Agar organisasi dapat tampil efektif, seyogyanya individu dan kelompok yang saling tergantung tersebut harus menciptakan hubungan kerja yang saling mendukung satu sama lain menuju pencapaian tujuan organisasi.

Hurduzeu, Kinerja karyawan sangat mempengaruhi keberhasilan organisasi. Kinerja karyawan merupakan prestasi kerja, yakni perbandingan antara hasil kerja nyata karyawan dengan standar kerja yang ditetapkan.[20] Setiap organisasi akan berusaha untuk selalu meningkatkan kinerja karyawannya demi tercapainya tujuan yang telah ditetapkan organisasi. Berbagai cara bisa ditempuh perusahaan dalam meningkatkan kinerja karyawannya; diantaranya dengan mewujudkan kepuasan kerja karyawan melalui iklim organisasi yang sesuai dengan harapan karyawan.

Karyawan menginginkan iklim yang akan memberi mereka kepuasan kerja. Kepuasan kerja karyawan ditunjukkan pada sikap yang positif menyangkut penyesuaian diri karyawan terhadap kondisi dan situasi kerja. Termasuk di dalamnya kondisi fisik, upah, dan kondisi psikologis. kepuasan kerja adalah kombinasi dari sikap positif dan negatif terhadap pencerminan tentang kebutuhan, keinginan, harapan dan penghargaan yang terdapat dalam diri seseorang terhadap pekerjaannya. Kepuasan kerja secara umum menyangkut sikap seseorang mengenai pekerjaannya. Dikarenakan menyangkut sikap, maka pengertian kepuasan kerja mencakup berbagai hal seperti kondisi dan kecenderungan perilaku seseorang. Kepuasan-kepuasan itu tidak tampak secara nyata, tetapi dapat diwujudkan dalam suatu hasil pekerjaan. Salah satu masalah yang sangat penting dalam bidang psikologi industri adalah mendorong karyawan untuk bekerja dengan lebih produktif. Untuk itu, perlu diperhatikan agar 
karyawan sebagai penunjang terciptanya produktivitas kerja dalam bekerja senantiasa disertai dengan perasaan senang dan tidak terpaksa; sehingga akan tercipta kepuasan kerja karyawan. Menurut Handoko, kepuasan kerja adalah keadaan emosional baik yang menyenangkan maupun tidak menyenangkan dimana karyawan memandang pekerjaan mereka [18]. Kepuasan kerja akan berbeda pada masingmasing individu. Sangat sulit untuk mengetahui ciri-ciri kepuasan dari masing-masing individu. Namun demikian, cerminan dari kepuasan itu dapat diketahui. Sehingga kepuasan kerja akan berbeda pada masing-masing individu. Vroom dalam Luthan, menggambarkan kepuasan kerja sebagai sikap positif terhadap pekerjaan pada diri seseorang [22]. Kepuasan kerja karyawan merupakan sasaran penting dalam manajemen sumber daya manusia, karena secara langsung atau tidak langsung dapat mempengaruhi kinerja karyawan. Para karyawan mencapai kepuasan kerja apabila mereka tertantang dan pencapaian mereka diketahui serta dihargai oleh pimpinan dan teman sejawat. Selain itu karyawan juga menginginkan iklim kerja yang memberikan kondisi kerja yang baik, gaji yang tinggi dan kesempatan untuk tumbuh dan berkembang menjadi karyawan yang profesional. Pengalaman dan pengembangan karier diharapkan membuat mereka mampu untuk menetapkan serta mengarahkan masa depan profesionalisme mereka. Dalam kondisi yang demikian, apabila Kepuasan Kerja karyawan sesuai dengan keinginan karyawan, maka akan semakin memperlancar organisasi dalam mencapai tujuannya. Untuk mencapai kondisi yang demikian, diperlukan adanya hubungan timbal balik yang seimbang antara pemimpin dan bawahan. Para pemimpin organisasi seyogianya menerapkan gaya kepemimpinan yang sesuai dengan situasi dan disukai oleh bawahan, sebaliknya bawahan juga seyogianya senantiasa meningkatkan prestasi kerjanya sehingga tujuan organisasi akan lebih mudah dicapai. Sesungguhnya, organisasi yang sukses selalu memperhatikan kepuasan kerja dan kinerja karyawan nya, Shmailan [27].

Kondisi ideal di atas tidak terjadi pada PT. Yuri Cakra Brothers. Berdasarkan studi pendahuluan yang peneliti lakukan menunjukkan bahwa kinerja karyawan yang bekerja di PT. Yuri Cakra Brothers belum dapat menjawab semua tuntutan organisasi. Kenyataan ini dapat dilihat dari lemahnya kerjasama antara karyawan di PT. Yuri Cakra Brothers seperti: (1) kualitas kerjasama yang masih rendah; (2) kuantitas kerja yang masih rendah; (3) kurangnya kehandalan para karyawan; (4) rendahnya inisiatif dari karyawan dalam melaksanakan pekerjaannya; dan (5) lemahnya kerjasama antara pimpinan dengan para karyawan. Berdasarkan kenyataan tersebut membuktikan bahwa kerjasama antara pimpinan dengan para karyawan belum berjalan dengan baik. Gaya kepemimpinan yang dilakukan oleh pemimpin PT. Yuri Cakra Brothers cenderung otokratik, artinya berbagai kebijakan yang seharusnya ditangani secara bersama-sama terkesan masih diambil alih oleh pimpinan.

Berdasarkan wawancara peneliti dengan beberapa karyawan PT. Yuri Cakra Brothers, ditemukan beberapa permasalahan; yaitu keinginan pimpinan yang mengharuskan adanya perbaikan terus menerus (continous improvement) sehingga menimbulkan keluhan-keluhan para karyawan yang tidak tersampaikan secara terbuka. Hal-hal tersebut dicurigai berpengaruh terhadap kepuasan kerja karyawan yang pada akhirnya dapat mempengaruhi kinerja. Melihat kondisi di atas, dapat diketahui begitu besarnya pengaruh iklim organisasi dan kepuasan kerja terhadap kinerja karyawan. Oleh karena itu, untuk mengetahui seberapa besar pengaruh 
variabel iklim organisasi dan kepuasan kerja terhadap kinerja karyawan maka peneliti membuat judul penelitian "Pengaruh Iklim Organisasi dan Kepuasan Kerja Karyawan terhadap Kinerja Karyawan pada PT. Yuri Cakra Brothers”.

PT. Yuri Cakra Brothers didirikan pada tahun 1992 yang berkedudukan di Kota Medan. Perusahaan ini awalnya bergerak dalam hal membangun sarana dan prasarana kelistrikan terutama untuk mengkoordinasikan perencanaan, membangun jaringan baru, pengoperasian dan pemeliharaan sarana pendistribusian tenaga listrik yang efektif, efisien serta menerapkan tata kelola perusahaan yang baik di wilayah kerja Kota Medan. Perkembangan perusahaan ini semakin pesat sejak dikeluarkannya peraturan pemerintah No. 23/1994 tanggal 16 Juni 1994 yang mengubah status PLN sebagai persero. Fungsi dan layanan tugas PLN dalam mengantisipasi kebutuhan listrik terus meningkat yang berdampak pada penambahan kontrak jaringan kerja PT. Yuri Cakra Brothers.

\section{Landasan Teori dan Penelitian Terdahulu.}

\section{Landasan Teori.}

\section{Pengertian Iklim Organisasi}

Iklim organisasi merupakan salah satu kajian yang muncul dalam upaya bagaimana seseorang pimpinan mengembangkan pola interaksi sosial sehingga tujuan organisasi dapat tercapai. Triatna mendefinisikan iklim organisasi sebagai lingkungan manusia yang saling bekerjasama dengan karyawannya di mana mereka bekerja [32]. Definisi tersebut merujuk pada suasana kerja yang dirasakan oleh personel berdasarkan interaksinya ketika ia berhubungan dengan personel lain dilingkungan kerjanya.

Litwin \& Stringer berpendapat bahwa iklim organisasi merupakan seperangkat persepsi orang-orang hidup dan bekerja dalam suatu lingkungan dan mempengaruhi perilaku mereka [21]. Lebih lanjut, Udar mengartikan iklim organisasi sebagai hal yang amat penting bagi keberhasilan suatu organisasi dan iklim suatu organisasi akan sangat berbeda dengan iklim organisasi lainnya, karena hal tersebut berkaitan dengan kondisi lingkungan kerja masing-masing organisasi [30]. Iklim organisasi juga merupakan konsep deskriptif yang berdasarkan pada persepsi lingkungan sosial anggota organisasi.

Merujuk pada pendapat para ahli di atas, dapat didefinisikan bahwa iklim organisasi adalah keseluruhan perasaan yang meliputi hal-hal fisik, bagaimana para karyawan berinteraksi dan bagaimana mereka mengendalikan diri dalam berhubungan dengan pelanggan atau pihak luar organisasi. Dari definisi tesebut dapat dilihat bahwa sebenarnya konsep iklim organisasi itu sendiri adalah sifat-sifat atau ciri-ciri yang dirasakan dalam lingkungan kerja dan timbul karena kegiatan organisasi tersebut dan dapat mempengaruhi perilaku orang-orang di dalamnya. Oleh karena itu, iklim organisasi saling berhubungan dan mempengaruhi antara kinerja yang dihasilkan karyawan dalam suatu organisasi. Sehingga, apabila iklim organisasi itu kondusif maka akan berdampak positif pula terhadap kinerja personil tetapi sebaliknya apabila iklim organisasi itu buruk maka akan berdampak negatif terhadap 


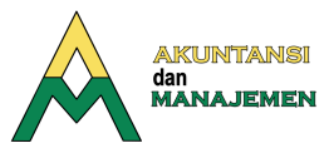

https://akuntansi.pnp.ac.id/jam

e-ISSN 2657-1080, p-ISSN 1858-3687

kinerja anggota organisasi yang membuat anggota organisasi merasa tidak nyaman dalam melakukan perkerjaannya.

Iklim organisasi yang baik dapat diukur dari lingkungan kerja yang baik dan kondisi tersebut secara langsung maupun tidak langsung berpengaruh pada karyawan dan pekerjaannya, dan juga akan berpengaruh pada motivasi dan perilaku karyawan. Dengan demikian, iklim organisasi itu merupakan kepribadian sebuah organisasi yang membedakan dengan organisasi lainnya yang mengarah pada persepsi masingmasing anggota dalam memandang organisasi.

\section{Pengertian Kepuasan Kerja}

Kepuasan kerja pada hakikatnya bersifat individual di mana setiap individu akan memiliki tingkat kepuasan yang berbeda-beda sesuai dengan sistem nilai yang berlaku pada dirinya. Hal ini disebabkan oleh adanya perbedaan pada masing-masing individu. Semakin banyak aspek-aspek dalam pekerjaan yang sesuai dengan keinginan individu tersebut maka semakin tinggi tingkat kepuasan yang dirasakannya dan sebaliknya. Kepuasan kerja menurut menurut Blum dalam bukunya Moch. As'ad, adalah sikap umum yang merupakan hasil dari beberapa sikap khusus terhadap faktor-faktor pekerjaan, menyesuaikan dan hubungan sosial individu diluar kerja [7]. Sedangkan Handoko mengemukakan bahwa kepuasan kerja merupakan sikap emosional karyawan dimana terjadi atau tidak terjadi titik temu antara nilai balas jasa kerja dari organisasi organisasi dengan nilai balas jasa yang diharapkan [18]. Senada dengan pendapat Handoko, Fortuna berpendapat bahwa kepuasan kerja (job satisfaction) adalah keadaan emosional karyawan yang terjadi maupun tidak terjadi titik temu antara nilai balas jasa kerja karyawan dan perusahaan atau organisasi dengan tingkat nilai balas jasa yang memang diinginkan oleh karyawan yang bersangkutan [14].

Berdasarkan pendapat tersebut di atas kepuasan kerja dapat diambil kesimpulan bahwa kepuasan kerja adalah suatu perasaan yang menyokong atau tidak menyokong diri karyawan yang berhubungan dengan pekerjaannya maupun dengan dirinya. Perasaan yang berhubungan dengan pekerjaan melibatkan aspek-aspek seperti upah atau gaji yang di terima, kesempatan pengembangan karir, hubungan dengan karyawan lainnya, mutu pengawasan. Sedangkan perasaan yang berhubungan dengan dirinya antara lain umur, kondisi kesehatan, kemampuan, pendidikan.

Karyawan akan merasa puas dalam bekerja apabila aspek-aspek pekerjaan dan aspek-aspek dirinya menyokong dan sebaiknya jika aspek-aspek tersebut tidak menyokong, karyawan akan merasa tidak puas.

Banyak faktor yang mempengaruhi kepuasan kerja karyawan. Faktor-faktor itu sendiri dalam peranannya memberikan kepuasan kepada karyawan tergantung pada pribadi masing-masing.

Para pakar telah mengembangkan berbagai desain mengenai kepuasan kerja. Wirawan, mengemukakan faktor-faktor kepuasaan kerja. Kepuasan kerja dan ketidakpuasaan kerja disebabkan oleh sejumlah faktor atau dimensi yang menyebabkan kepuasan dan ketidakpuasan kerja [33]. Jika persepsi pegawai terhadap faktor tersebut positif maka pegawai akan puas terhadap pekerjaannya. Jika persepsi pegawai negatif, maka pegawai akan tidak puas terhadap pekerjaannya. 


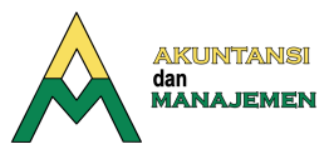

https://akuntansi.pnp.ac.id/jam

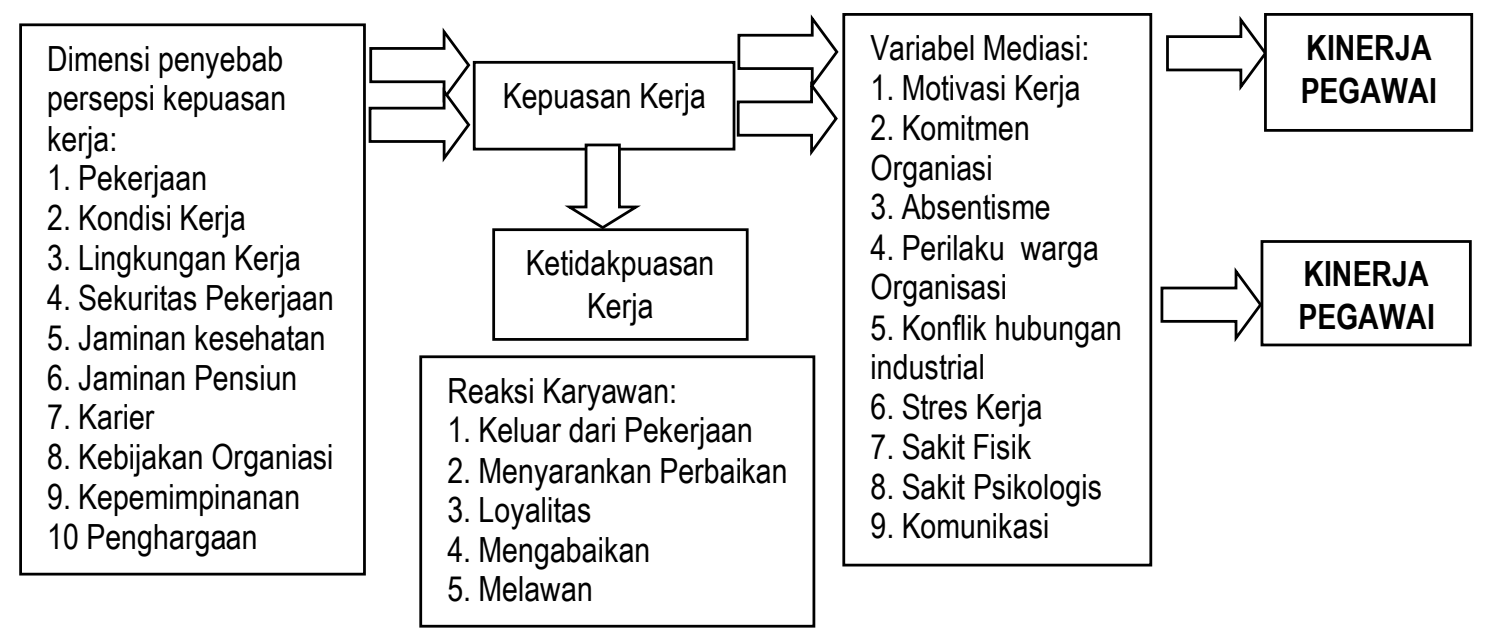

Gambar 1. Model Kepuasan Kerja

Puas dan tidak puas pegawai terhadap pekerjaannya mempengaruhi variabel mediasi yaitu variabel antara kepuasaan kerja dan ketidakpuasaan kerja dengan kinerja pegawai. Jika pengaruh variabel mediasi tinggi, maka kinerja pegawai relatif tinggi. Dikatakan relatif tinggi, karena kinerja pegawai berfluktuasi dipengaruhi keadaan lingkungan kerja. Jika pengaruhnya rendah, kinerja pegawai relatif akan rendah. Keadaan tersebut akan menentukan tujuan perusahaan.

\section{Pengertian Kinerja}

Istilah kinerja berasal dari kata Job Performance atau Actual Performance (prestasi kerja atau prestasi sesungguhnya yang dicapai oleh seseorang). Pengertian kinerja (prestasi Kerja). Kinerja merupakan suatu pencapaian berhasil atau tidaknya tujuan organisasi yang telah ditetapkan. Informasi tentang kinerja organisasi adalah hal yang sangat penting yang digunakan untuk mengevaluasi apakah proses kinerja yang dilakukan organisasi selama ini sudah sejalan dengan tujuan yang diharapkan atau belum.

Hakim mendefinisikan kinerja sebagai hasil kerja yang dicapai oleh individu yang disesuaikan dengan peran atau tugas individu tersebut dalam suatu perusahaan pada suatu periode waktu tertentu, yang dihubungkan dengan suatu ukuran nilai atau standar tertentu dari perusahaan tempat individu tersebut bekerja [4]. Lebih lanjut menurut Rani dan Mayasari mengemukakan kinerja adalah sebagai hasil dari pekerjaan yang terkait dengan tujuan organisasi seperti: kualitas, efisiensi dan kriteria efektivitas kerja lainnya. [26]

Secara umum dapat dikatakan bahwa kinerja merupakan wujud atau keberhasilan pekerjaan seseorang atau organisasi dalam rangka pencapaian tujuan. Hasil atau kinerja suatu organisasi dapat dicapai dengan baik antara lain atas beberapa pengaruh dari pembagian tugas, wewenang dan tanggung jawab yang jelas dari para peserta pekerja di dalam organisasi tersebut.

Pembagian tugas wewenang dan tanggung jawab itu dalam pelaksananya harus diiringi dengan disiplin yang tinggi, tidak melanggar hukum hubungan kerjasama 


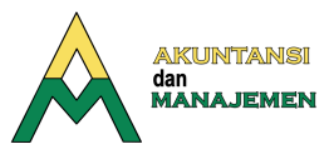

https://akuntansi.pnp.ac.id/jam

e-ISSN 2657-1080, p-ISSN 1858-3687

vertikal dan horisontal yang harmonis dengan di dukung oleh fasilitas yang memadai berupa sarana dan prasarana serta lingkungan yang aman dan nyaman, sehingga semua tugas, wewenang dan tanggung jawab tersebut dapat berjalan dengan baik.

\section{Penelitian Terdahulu}

Penelitian yang terkait dengan iklim organisasi dan kepuasan kerja terhadap kinerja karyawan bahwa iklim organisasi dan kepuasan kerja memberikan sumbangan yang sangat berarti bagi kinerja karyawan. Iklim organisasi merupakan ciri-ciri khas yang menggambarkan lingkungan psikologik suatu organisasi yang menunjukkan isi dari kekuatan dan pengaruh antara nilai, norma, sikap, perilaku dan perasaan anggota tersebut. Iklim organisasi ini dapat mempengaruhi manusia yang bekerja di dalamnya melalui sentuhan tidak tampak mata. Umpan balik yang memberikan rangsangan untuk bekerja dengan cara yang lebih efisien dan efektif daripada sebelummya akan menyebabkan terjadinya kepuasan kerja karyawan. Bila iklim organiasi merangsang kepuasan kerja maka kinerja karyawan menyediakan saran bagi pemuasan berbagai kebutuhan penting para pekerja, maka sumbangan iklim organisasi bagi kepuasan kerja dapat diharapkan cukup besar. Jika iklim organisasi berorientasi pada kinerja dan merangsang kepuasan kerja karyawan kondisi ini mendukung para karyawan untuk bekerja dengan segenap kemampuan maka akan timbul tingkah laku yang kreatif dan produksi yang tinggi serta kinerja yang tinggi pula, karena seorang yang mempunyai kepuasan kerja yang tinggi lebih menyukai untuk bekerja keras, lebih efisien, lebih cepat dan lebih menyukai pekerjaan mereka sehingga dengan cara tersebut dapat diperoleh kepuasan yang lebih besar.

Dodi, meneliti tentang pengaruh iklim organisasi, etos kerja dan disiplin terhadap kinerja karyawan serta dampaknya pada kinerja PT. Arun NGL Lhokseumawe Aceh [13]. Hasil penelitian tersebut menemukan bahwa kinerja karyawan berpengaruh terhadap kinerja organisasi, iklim organisasi, etos kerja dan disiplin kerja berpengaruh terhadap kinerja organisasi melalui kinerja karyawan. Hasil penelitiannya juga menunjukkan bahwa iklim organisasi, etos kerja dan disiplin kerja secara simultan berpengaruh terhadap kinerja organisasi PT. Arun NGL Lhokseumawe. Terkait dengan variabel iklim organisasi dan pengaruhnya terhadap kinerja, penelitian Dodi membuktikan bahwa iklim organisasi mempunyai pengaruh nyata terhadap peningkatan kinerja PT. Arun NGL Lhokseumawe Aceh diperoleh nilai koefisien sebesar 0,464 artinya setiap perubahan terhadap variabel iklim organisasi sebanyak 100 persen, maka akan meningkatkan kinerja karyawan sebanyak 46,4\% pada satuan Skala Likert.

Selanjutnya, Husnawati dalam penelitiannya mengemukakan bahwa kepuasan kerja mempunyai pengaruh terhadap kinerja karyawan dan dapat ditingkatkan melalui lima dimensi yaitu pekerjaan itu sendiri, bayaran, kesempatan promosi, atasan dan rekan kerja [19] . Berdasarkan standardized regression weight dapat diketahui bahwa indikator atasan merupakan indikator komitmen organisasi yang paling berpengaruh dalam meningkatkan kinerja dengan nilai estimasi sebesar 0.82 sedangkan indikator kesempatan promosi merupakan indikator yang paling kecil pengaruhnya terhadap kinerja. Hal ini menunjukkan pentingnya dibina hubungan yang harmonis antara atasan dengan bawahan sehingga karyawan dalam 
melaksanakan tugasnya mendapatkan dorongan moral dan perlindungan dari atasan. Hal ini akan berakibat pada meningkatnya rasa aman dalam bekerja dan secara tidak langsung akan berpengaruh kepada kinerja kayawan yang bersangkutan. Di samping itu perlu kiranya manajemen untuk melihat kembali sistem pengembangan karir bagi karyawan sehingga diharapkan memacu karyawan untuk berprestasi dan mendapatkan promosi dari perusahaan.

Penelitian yang relevan tentang variabel kepuasan kerja dikemukakan oleh Prasetyo yang membuktikan bahwa variabel kepuasan dan iklim organisasi mempunyai pengaruh yang positif dan signifikan terhadap produktivitas kerja karyawan [23]. Temuan penelitiannya mendukung hasil penelitian ini yang menyatakan iklim organisasi mempunyai pengaruh positif dan signifikan terhadap produktivitas kerja karyawan,

Penelitian tentang variabel kepuasan kerja dan kinerja oleh De Rego menyatakan bahwa ada pengaruh positif dan signifikan antara kepuasan kerja dengan kinerja pegawai Kejaksaan Agung dan Kejaksaan Distrik Dili [12]. Hasil ini ditunjukkan dengan besarnya nilai signifikansi uji t variabel Kepuasan Kerja sebesar 0,020. Nilai signifikansi uji $t<0,05$, sehingga ada pengaruh positif yang signifikan antara variabel kepuasan kerja terhadap Kinerja pegawai Kejaksaan Agung dan Kejaksaan Distrik Dili.

\section{Kerangka Pemikiran}

\section{Pengaruh Iklim Organisasi terhadap Kinerja Karyawan}

Kinerja merupakan prestasi dan hasil yang telah dicapai oleh karyawan. Setiap karyawan yang bekerja dapat dilihat dari perbuatan, pelaksanaan pekerjaan, pertunjukan dan pelaksanaan kontrak sesuai dengan syarat-syarat yang ditentukan bersama. Kinerja karyawan sangat dipengaruhi oleh iklim organisasi dimana karyawan bekerja.

Tempat kerja baik fisik maupun non fisik yang mendukung pelaksanaan tugas dalam organisasi; asalkan tempat kerja itu didukung sarana kerja, kenyamanan ruang kerja, kejelasan tugas, hubungan yang baik dengan atasan dan rekan kerja, serta sistem penghargaan dan sanksi yang adil. Karyawan akan memiliki kinerja yang baik; mereka dapat melaksanakan tugas-tugas pekerjaannya sesuai dengan kewenangan dan tanggung jawabnya dalam upaya mencapai tujuan organisasi. Dengan demikian, di duga terdapat pengaruh iklim organisasi terhadap kinerja seluruh karyawan dan mempunyai dimensi yang signifikan terhadap kepuasan kerja dengan adanya imbalan, tanggung jawab, standar pelaksanaan pekerjaan dan kepemimpinan yang baik

\section{Pengaruh Kepuasan Kerja terhadap Kinerja Karyawan}

Kepuasan kerja bukanlah hal yang sederhana; salah satu buktinya adalah sukarnya menemukan jawaban pertanyaan apakah ada kaitan antara kepuasan kerja dengan kinerja seseorang. Namun demikian seorang karyawan yang "puas" dengan kinerjanya tidak dengan sendirinya merupakan karyawan yang berprestasi tinggi; dapat pula 


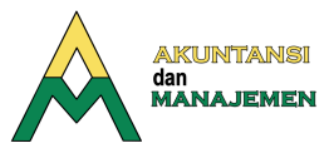

https://akuntansi.pnp.ac.id/jam

e-ISSN 2657-1080, p-ISSN 1858-3687

dikatakan bahwa kepuasan kerja tidak selalu menjadi faktor motivasi kuat terhadap kinerjanya.

Kepuasan kerja dan kinerja saling berkaitan meskipun kenyataan bahwa keduanya disebabkan oleh hal yang berbeda. Organisasi yang memiliki karyawan yang lebih puas cenderung lebih efektif dalam bekerja dibandingkan organisasi yang memiliki karyawan yang kurang puas dalam melaksanakan pekerjaannya. Seorang karyawan yang puas dengan pekerjaannya tentunya akan meningkatkan kinerja karyawan. Karyawan yang puas dalam melakukan pekerjaannya memiliki banyak cara untuk mendefinisikan dan memikul tanggung jawab atas pekerjaan yang telah diembannya. Mereka akan memanfaatkan kesempatan yang diberikan perusahaan untuk menikmati dan menggunakan fasilitas yang telah disediakan. Mereka akan bekerja dan beraktifitas secara fleksibel tanpa merasa tertekan dan memiliki kebebasan untuk mengembangkan diri di luar kepentingan instansi, selama tidak menimbulkan dampak negatif bagi tempat kerja.

Dalam suasana yang demikan, kinerja karyawan akan tumbuh secara bersamasama. Kinerja karyawan akan tumbuh bukan saja di dalam sebuah kelompok namun menyebar dalam skala yang luas menjadi kinerja organisasi. Jika kinerja organisasi tumbuh secara baik tentunya akan berdampak pada pencapaian tujuan yang jelas, tujuan yang jelas karena ketika berbicara kinerja, karyawan bukan hanya tumbuh sendirian, tetapi mereka akan tumbuh secara bersama-bersama untuk memajukan organisasi. Adalah pemilikan atau kebersamaan. Kinerja merujuk kepada adanya kebersamaan. Berdasarkan pemaparan di atas, di duga ada pengaruh antara kepuasan kerja terhadap kinerja karyawan.

\section{Pengaruh iklim organisasi dan kepuasan kerja terhadap kinerja karyawan}

Kepuasan kerja merupakan suatu sikap yang timbul berdasarkan penilaian kinerja. Sesungguhnya, organisasi yang memiliki karyawan yang lebih puas cenderung lebih efektif dibandingkan organisasi yang memiliki karyawan yang kurang puas. Hal ini dikarenakan adanya kepuasan kerja yang dimiliki karyawan menghasilkan kinerja yang memuaskan bagi mereka. Kinerja dimaknai sebagai perbuatan, pelaksanaan, pertunjukan, dan pelaksanaan kontrak sesuai dengan syarat-syarat yang ditentukan bersama. Seorang yang sudah merasa puas dalam melaksanakan pekerjaannya tentunya perbuatan, pelaksanaan pekerjaannya sudah sesuai dengan syarat-syarat dan kontrak kerja yang telah mereka sepakati dengan perusahaan.

Iklim organisasi adalah keadaan di tempat kerja baik fisik maupun non fisik yang mendukung pelaksanaan tugas dalam organisasi dengan indikator kelengkapan sarana kerja, kenyamanan ruang kerja, kejelasan tugas, hubungan yang baik dengan atasan dan rekan kerja, serta sistem penghargaan dan sanksi yang adil. Sementara kinerja adalah untuk kerja yang dapat dicapai oleh seseorang dalam melaksanakan tugas-tugas pekerjaannya sesuai dengan kewenangan dan tanggung jawabnya dalam upaya mencapai tujuan organisasi. Berdasarkan pemaparan di atas di duga terdapat pengaruh iklim organisasi terhadap kinerja seluruh karyawan mempunyai dimensi yang signifikan terhadap kepuasan kerja dengan adanya imbalan, tanggung jawab, standar pelaksanaan pekerjaan dan kepemimpinan. 


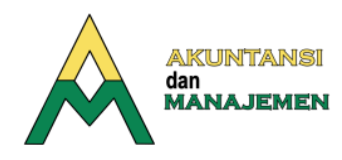

https://akuntansi.pnp.ac.id/jam

\section{Metode Penelitian}

Penelitian ini bersifat deskriptif kuantitatif, yaitu menggambarkan keadaan yang ada pada objek penelitian. Analisa data yang digunakan adalah analisa statistik univariat; yang mencakup frekuensi distribusi, test validasi dan reliabilitas dilanjutkan dengan Analisa regresi bivariat. Untuk pembahasan digunakan uji korelasi untuk mencari ada tidaknya hubungan antara variabel; apabila ada, berupa: eratnya hubungan dan berarti atau tidaknya hubungan itu, Arikunto [6]. Sampel dalam penelitian ini adalah seluruh karyawan di PT. Yuri Cakra Brothers yang bekerja yaitu sebanyak 36 orang.

Kerangka pikir pada penelitian ini dimulai dengan operasionalisasi variabel dari dimensi Kinerja Karyawan, Iklim Organisasi dan Kepuasan Kerja. Dimensidimensi ini juga berhubungan dengan respons karyawan terhadap sistem penilaian Kinerja Karyawan yang mereka peroleh; apakah puas atau tidak puas.

Untuk mendapatkan gambaran yang jelas tentang kerangka berpikir dalam penelitian ini, penulis gambarkan berikut ini:

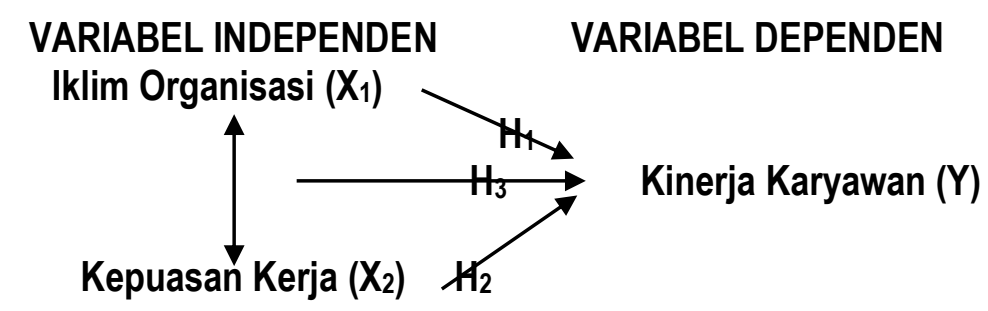

\section{Gambar 2. Kerangka Pikir}

Keterangan :

$\mathrm{X}_{1}$ : Iklim Organisasi.

$\mathrm{X}_{2}$ : Kepuasan Kerja.

Y : Kinerja Karyawan.

Adapun hipotesis yang diajukan adalah :

Ha1: Ada pengaruh yang signifikan antara Iklim Organisasi terhadap Kinerja Karyawan.

Ha2: Ada pengaruh yang signifikan antara Kepuasan Kerja terhadap Kinerja Karyawan

На3: Ada pengaruh yang signifikan antara Iklim Organisasi dan Kepuasan Kerja secara bersama-sama terhadap Kinerja Karyawan

\section{Hasil Penelitian Dan Pembahasan}

\section{Hasil Penelitian}

\section{Pengujian Persyaratan Analisis}

Uji asumsi klasik harus dipenuhi agar mendapatkan model regresi dengan estimasi yang tidak bias dan pengujian yang dapat diandalkan; yaitu: 


\section{M}

https://akuntansi.pnp.ac.id/jam

e-ISSN 2657-1080, p-ISSN 1858-3687

\section{Uji Normalitas}

Uji ini dilakukan dengan menggunakan teknik Kolmogorov - Smirnov Goodness of Fit Test. Teknik ini digunakan karena data yang akan diuji berada dalam level interval. Selain itu, teknik ini lebih ketat dibandingkan dengan $\mathrm{X}$ karena teknik ini memperlakukan observasi individual secara terpisah sehingga tidak seperti X, tidak perlu kehilangan informasi karena pembuatan kategorisasi. Suatu data dikatakan normal jika nilai $\mathrm{p}>0.05$ [Field, 2000].

Tabel 1 Hasil Uji Normalitas

\begin{tabular}{|c|c|c|c|c|}
\hline \multicolumn{5}{|c|}{ One-Sample Kolmogorov-Smirnov Test } \\
\hline & & Iklim Organiasi & $\begin{array}{l}\text { Kepuasan } \\
\text { Kerja }\end{array}$ & Kinerja Karyawan \\
\hline \multicolumn{2}{|c|}{$\mathrm{N}$} & 36 & 36 & 36 \\
\hline \multirow{2}{*}{$\begin{array}{c}\text { Normal } \\
\text { Parameters }, \mathrm{b}\end{array}$} & Mean & 23.42 & 23.42 & 25.08 \\
\hline & Std. Deviation & 1.842 & 2.143 & 1.962 \\
\hline \multirow{3}{*}{$\begin{array}{c}\text { Most Extreme } \\
\text { Differences }\end{array}$} & Absolute & .133 & .143 & .124 \\
\hline & Positive & .089 & .143 & .100 \\
\hline & Negative & -.133 & -.107 & -.124 \\
\hline \multicolumn{2}{|c|}{ Test Statistic } & .133 & .143 & .124 \\
\hline \multicolumn{2}{|c|}{ Asymp. Sig. (2-tailed) } & $.110^{c}$ & $.061^{\mathrm{c}}$ & $.180^{\circ}$ \\
\hline \multicolumn{5}{|c|}{ a. Test distribution is Normal. } \\
\hline \multicolumn{5}{|c|}{ b. Calculated from data. } \\
\hline \multicolumn{5}{|c|}{ c. Lilliefors Significance Correction. } \\
\hline
\end{tabular}

Berdasarkan pada Tabel 1 One-Sample Kolmogorov-Smirnov Test dapat dijelaskan bahwa nilai $\mathrm{p}=0,11$ untuk variabel Iklim Organisasi $\left(\mathrm{X}_{1}\right)$ berarti nilai $\mathrm{p}>$ 0,05 , kemudian nilai $\mathrm{p}=0,061$ untuk variabel Kepuasan Kerja $\left(\mathrm{X}_{2}\right)$ berarti nilai $\mathrm{p}>$ 0,05 , dan nilai $\mathrm{p}=0,180$ untuk variabel kinerja $(\mathrm{Y})$, berarti nilai $\mathrm{p}>0,05$, maka dapat dikatakan bahwa data variabel Iklim Organisasi ( $\left.\mathrm{X}_{1}\right)$, Kepuasan Kerja ( $\mathrm{X}_{2}$ ) dan Kinerja Karyawan (Y) adalah normal.

Untuk lebih jelasnya dapat digambarkan dengan diagram pencar uji normalitas, sebagai berikut:

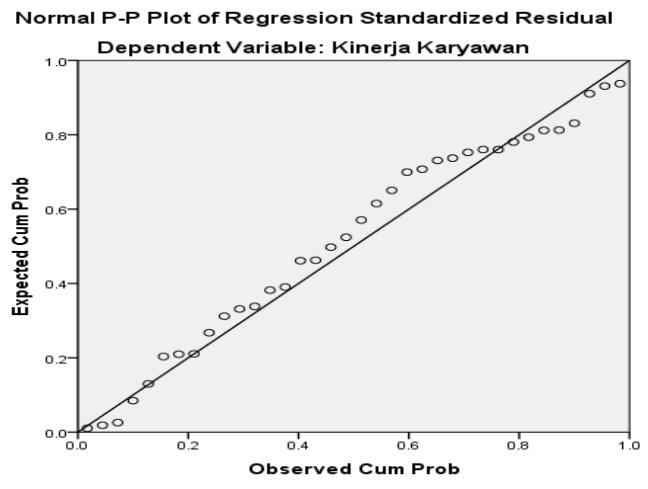

Gambar 3. Hasil Uji Normalitas

Maka dari Gambar 2 dapat disimpulkan bahwa data dari penelitian ini adalah normal, dapat dilihat dari titik-titik yang menyebar mengikuti garis diagonal sehingga dikatakan bahwa model regresi layak dipakai untuk memenuhi asumsi normalitas. 


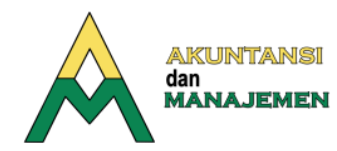

https://akuntansi.pnp.ac.id/jam

e-ISSN 2657-1080, p-ISSN 1858-3687

\section{Uji Homogenitas}

Pendekatan Levene biasanya akan langsung disajikan oleh SPSS ketika kita melakukan F-test untuk sampel yang independent. Dari nilai F-test yang didapatkan dari F-test dibandingkan dengan $F_{\text {tabel. }}$ Hal ini dapat dilihat pada Tabel 2 dibawah ini:

Tabel 2 Hasil Uji Homogenitas

\begin{tabular}{|c|c|c|c|c|c|c|c|c|c|c|}
\hline \multicolumn{11}{|c|}{ Independent Samples Test } \\
\hline & & $\begin{array}{l}\text { Leven } \\
\text { for Ec } \\
\text { Varian }\end{array}$ & $\begin{array}{l}\text { Test } \\
\text { lality of } \\
\text { es }\end{array}$ & \multicolumn{7}{|c|}{ t-test for Equality of Means } \\
\hline & & \multirow[t]{2}{*}{$F$} & \multirow[t]{2}{*}{ Sig. } & \multirow[t]{2}{*}{$\mathrm{t}$} & \multirow[t]{2}{*}{ df } & \multirow[t]{2}{*}{$\begin{array}{l}\text { Sig.(2 } \\
\text { tailed) }\end{array}$} & \multirow[t]{2}{*}{$\begin{array}{l}\text { Mean } \\
\text { Difference }\end{array}$} & \multirow{2}{*}{$\begin{array}{l}\text { Std. } \\
\text { Error } \\
\text { Differen } \\
\text { ce }\end{array}$} & \multicolumn{2}{|c|}{$\begin{array}{l}95 \% \text { Confidence } \\
\text { Interval of the } \\
\text { Difference }\end{array}$} \\
\hline & & & & & & & & & Lower & Upper \\
\hline $\begin{array}{l}\text { V } \\
\text { a } \\
\text { ri }\end{array}$ & $\begin{array}{l}\text { Equal } \\
\text { variances } \\
\text { assumed }\end{array}$ & 0.003 & 0.95 & 0.13 & 70 & 0.9 & 0.056 & 0.441 & -0.82 & 0.935 \\
\hline $\begin{array}{l}a \\
b \\
\text { el }\end{array}$ & $\begin{array}{l}\text { Equal } \\
\text { variances not } \\
\text { assumed }\end{array}$ & & & 0.13 & 69.93 & 0.9 & 0.056 & 0.441 & -0.82 & 0.935 \\
\hline
\end{tabular}

Uji homogenitas dengan hasil sebagai berikut: Berdasarkan hasil perhitungan didapat F-test $=0,03$ dengan $\rho=0,95$ dan $F_{\text {tabel }}(n-2) \cdot(1)$ df: $(36-2)=34$, berarti $\rho>0,05(0,95$ $>0,05)$ dan F-test $<F_{\text {tabel }}(0,003<4,08)$, maka dapat dikatakan bahwa data variabel Iklim Organisasi $\left(\mathrm{X}_{1}\right)$ dan Kepuasan Kerja $\left(\mathrm{X}_{2}\right)$ adalah homogen.

\section{Uji Multikolinieritas}

Uji multikolinieritas dilakukan untuk menguji apakah pada model regresi ditemukan adanya korelasi antara variabel bebas. Model regresi yang baik seharusnya tidak terjadi korelasi di antara variabel bebas, Ghozali [15].

Dengan dasar pengambilan keputusan:

a. Nilai Tolerance $<10 \%$ dan nilai VIF (Variance Infaltion Factor) $>10$, maka Ho diterima yang artinya terjadi multikolinieritas antar variabel bebas dalam model regresi.

b. Nilai Tolerance $>10 \%$ dan nilai VIF (Variance Infaltion Factor) $<10$, maka Ho tidak diterima yang artinya tidak terjadi multikolinieritas antar variabel bebas dalam model regresi.

\section{Tabel 3 Hasil Uji Multikolinieritas}

\begin{tabular}{|c|c|c|c|c|c|c|c|}
\hline \multicolumn{8}{|l|}{ Coefficients $^{a}$} \\
\hline \multirow[b]{2}{*}{ Model } & \multicolumn{3}{|c|}{\begin{tabular}{|l|l|} 
Unstandardized Coefficients & Standardized \\
Coefficients
\end{tabular}} & \multirow[b]{2}{*}{$\mathrm{t}$} & \multirow[b]{2}{*}{ Sig. } & \multicolumn{2}{|c|}{ Collinearity Statistics } \\
\hline & $B$ & Std. Error & Beta & & & Tolerance & VIF \\
\hline \begin{tabular}{|l|l|}
1 & (Constant) \\
\end{tabular} & 19.826 & 4.361 & & 4.546 & .000 & & \\
\hline Iklim Organiasi & .159 & 349 & 149 & .457 & .651 & .271 & 3.693 \\
\hline Kepuasan Kerja & .065 & .338 & .063 & .194 & .848 & .271 & 3.693 \\
\hline
\end{tabular}

a. Dependent Variable: Kinerja Karyawan 
Berdasarkan Tabel 3 di atas, dapat dijelaskan bahwa nilai tolerance, yaitu 0,271>0,10 dan VIF, yaitu $3.693<10$, dengan demikian tidak ada multikolinieritas antara variabel bebas dalam model regresi.

\section{Uji Heterokedastisitas}

Uji Heterokedastisitas digunakan untuk menguji apakah dalam sebuah model regresi terjadi ketidaksamaan varians dari residual satu pengamatan ke pengamatan yang lain; Ghozali [15]. Model regresi yang baik adalah apabila tidak terjadi heterokedastisitas.

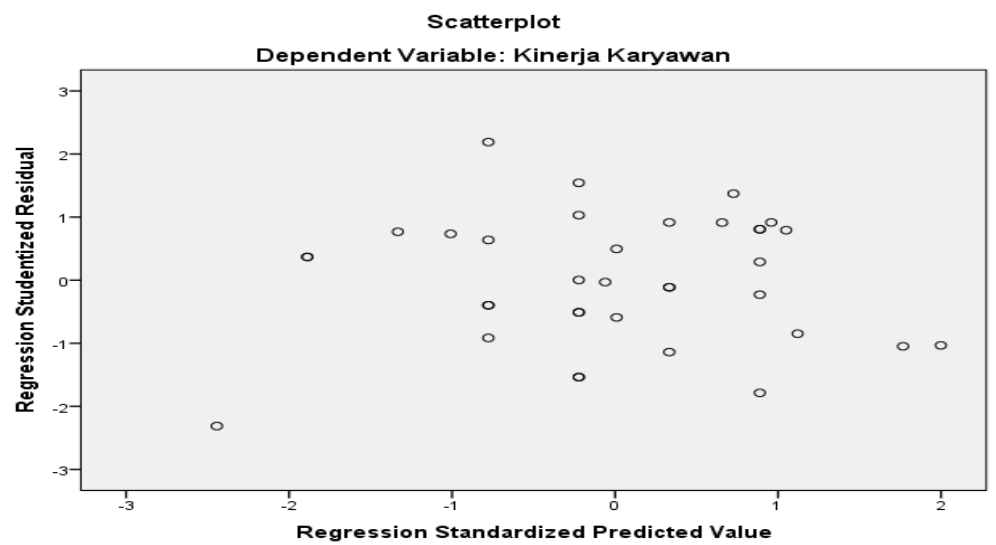

Gambar 4. Hasil Uji Heterokedastisitas

Berdasarkan Gambar 3 di atas, dapat disimpulkan bahwa tidak terjadi heterokedastisitas pada model regresi. Karena terlihat titik-titik menyebar secara acak tidak membentuk sebuah pola tertentu yang jelas serta tersebar baik di atas maupun di bawah 0 pada sumbu Y.

\section{Pengujian Hipotesis}

Setelah dilakukan beberapa pengujian persyaratan analisis ternyata penelitian ini layak dilanjutkan dengan analisis hipotesis; yaitu:

Tabel 4 Hasil Regresi Sederhana Antara Iklim Organisasi Terhadap Kinerja Karyawan

\begin{tabular}{|c|c|c|c|c|c|c|}
\hline \multicolumn{7}{|c|}{ Coefficients $^{a}$} \\
\hline & \multirow[b]{2}{*}{ Model } & \multicolumn{2}{|c|}{$\begin{array}{c}\text { Unstandardized } \\
\text { Coefficients }\end{array}$} & \multirow{2}{*}{$\begin{array}{c}\begin{array}{c}\text { Standardized } \\
\text { Coefficients }\end{array} \\
\text { Beta }\end{array}$} & \multirow[b]{2}{*}{$t$} & \multirow[b]{2}{*}{ Sig. } \\
\hline & & $B$ & Std. Error & & & \\
\hline \multirow[t]{2}{*}{1} & (Constant) & 20.006 & 4.201 & & 4.762 & .000 \\
\hline & Iklim Organiasi & .217 & .179 & .204 & 1.212 & .234 \\
\hline
\end{tabular}




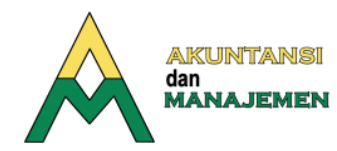

https://akuntansi.pnp.ac.id/jam

e-ISSN 2657-1080, p-ISSN 1858-3687

Persamaan regresi pada Tabel 4 di atas adalah sebagai berikut:

$$
\begin{aligned}
& \hat{Y}=a+b_{1} X_{1}+e \\
& \hat{Y}=20,006+0,217 X_{1}+e
\end{aligned}
$$

Keterangan:

$\mathrm{Y}=$ Kinerja

$\mathrm{a}=$ konstanta

$\mathrm{X}_{1}=$ Iklim Organisasi

Berdasarkan hasil pengolahan SPSS 24.0 diperoleh konstanta sebesar 20,006 menyatakan bahwa variabel kinerja dianggap konstan, maka variabel Iklim Organisasi adalah sebesar 0,217. Kemudian untuk nilai koefisien regresi Iklim Organisasi sebesar 0,217 menyatakan bahwa apabila nilai dari Iklim Organisasi naik sebesar satu satuan maka kinerja naik sebesar 0,217.

Perumusan hipotesis kedua adalah: $\mathrm{Ha}_{2}$ : Ada pengaruh signifikan antara Kepuasan Kerja terhadap Kinerja Karyawan pada PT. Yuri Cakra Brothers. Untuk mengetahui hipotesis di atas, maka dilakukan uji regresi sederhana antara variabel Kepuasan Kerja sebagai variabel bebas (independent) terhadap variabel kinerja sebagai variabel terkait (dependent). Hasil pengujian regresi adalah sebagai berikut:

\begin{tabular}{|c|c|c|c|c|c|c|}
\hline \multicolumn{7}{|c|}{ Coefficients $^{a}$} \\
\hline \multirow{2}{*}{\multicolumn{2}{|c|}{ Model }} & \multicolumn{2}{|c|}{ Unstandardized Coefficients } & $\begin{array}{c}\text { Standardized } \\
\text { Coefficients }\end{array}$ & \multirow[b]{2}{*}{$t$} & \multirow[b]{2}{*}{ Sig. } \\
\hline & & $\mathrm{B}$ & Std. Error & Beta & & \\
\hline \multirow[t]{2}{*}{1} & (Constant) & 20.475 & 4.075 & & 5.024 & .000 \\
\hline & Kepuasan Kerja & .197 & .174 & .191 & 1.135 & .265 \\
\hline
\end{tabular}

Tabel 5 Hasil Regresi Sederhana Antara Kepuasan Kerja Terhadap Kinerja Karyawan

Persamaan regresi pada Tabel 5 di atas adalah sebagai berikut:

$$
\begin{aligned}
& \hat{Y}=a+b_{2} X_{2}+e \\
& \hat{Y}=20,475+0,197 X_{2}+e
\end{aligned}
$$

Keterangan:

$\mathrm{Y}=$ Kinerja

$\mathrm{a}=$ Konstanta

$\mathrm{X}_{2}=$ Kepuasan Kerja

Berdasarkan hasil pengolahan SPSS 24.0 diperoleh konstanta sebesar 20,475 menyatakan bahwa variabel kinerja dianggap konstan, maka variabel Kepuasan Kerja adalah sebesar 0,197. Kemudian untuk nilai koefisien regresi Kepuasan Kerja sebesar 0,197 menyatakan bahwa apabila nilai dari Kepuasan Kerja naik sebesar satu satuan maka kinerja akan naik sebesar 0,197.

Perumusan hipotesis yang ketiga adalah: $\mathrm{Ha}_{3}$ : Ada pengaruh signifikan antara Iklim Organisasi dan Kepuasan Kerja secara bersama-sama terhadap Kinerja Karyawan pada PT. Yuri Cakra Brothers.

Untuk mengetahui hipotesis di atas, maka dilakukan analisa regresi berganda antara variabel Iklim Organisasi dan Kepuasan Kerja sebagai variabel bebas (independent) terhadap variabel Kinerja Karyawan sebagai variabel terkait (dependent). Hasil pengujian regresi adalah sebagai berikut: 
Tabel 6 Hasil Regresi Ganda Antara Iklim Organisasi dan Kepuasan Kerja terhadap Kinerja Karyawan

\begin{tabular}{|c|c|c|c|c|c|c|}
\hline \multicolumn{7}{|c|}{ Coefficients $^{a}$} \\
\hline \multirow{2}{*}{\multicolumn{2}{|c|}{ Model }} & \multicolumn{2}{|c|}{$\begin{array}{c}\text { Unstandardized } \\
\text { Coefficients }\end{array}$} & $\begin{array}{c}\text { Standardized } \\
\text { Coefficients }\end{array}$ & \multirow[b]{2}{*}{$t$} & \multirow[b]{2}{*}{ Sig. } \\
\hline & & $\mathrm{B}$ & Std. Error & Beta & & \\
\hline \multirow[t]{3}{*}{1} & (Constant) & 19.826 & 4.361 & & 4.546 & .000 \\
\hline & Kepuasan Kerja & .065 & .338 & .063 & .194 & .848 \\
\hline & Iklim Organiasi & .159 & .349 & .149 & .457 & .651 \\
\hline
\end{tabular}

Persamaan regresi pada Tabel 6 di atas adalah sebagai berikut:

$$
\begin{aligned}
& \hat{Y}=a+b_{1} X_{1}+b_{2} X_{2}+e \\
& \hat{Y}=19,826+0,065 X_{1}+0,159 X_{2}+e
\end{aligned}
$$

Berdasarkan pada Tabel 6 dapat dijelaskan bahwa dari persamaan tersebut dapat dikemukakan bahwa variabel kepuasan kerja dan iklim organisasi secara bersama-sama berpengaruh signifikan terhadap variabel kinerja karyawan.

\begin{tabular}{|c|c|c|c|c|}
\hline \multicolumn{5}{|c|}{ Model Summaryb } \\
\hline Model & $\mathrm{R}$ & R Square & $\begin{array}{l}\text { Adjusted R } \\
\text { Square }\end{array}$ & $\begin{array}{l}\text { Std. Error of the } \\
\text { Estimate }\end{array}$ \\
\hline 1 & $.606^{\mathrm{a}}$ & .043 & .416 & 1.977 \\
\hline \multicolumn{5}{|c|}{ a. Predictors: (Constant), Iklim Organiasi, Kepuasan Kerja } \\
\hline \multicolumn{5}{|c|}{ b. Dependent Variable: Kinerja Karyawan } \\
\hline
\end{tabular}

Tabel 7

Tabel 7 di atas menunjukkan nilai Coefficient Colleration (R) yang berarti Iklim Organisasi dan Kepuasan Kerja memiliki keeratan hubungan secara bersama-sama dengan Kinerja Karyawan sebesar 0,606 artinya adalah memiliki hubungan yang kuat (terletak pada letak internal koefisien 0,600- 0,799) Sugiyono (2010: h. 216).

Besarnya Adjusted $R$ square sebesar 0,416 atau 41,6\% artinya bahwa variabel Iklim Organisasi dan Kepuasan Kerja dapat menjelaskan variabel Kinerja Karyawan secara linier sebesar 41,6\%. Atau ada 58,4\% yang tidak dapat dijelaskan secara linier oleh variabel variabel Iklim Organisasi dan Kepuasan Kerja, maka Iklim Organisasi dan Kepuasan Kerja merupakan variabel yang sangat baik untuk menjelaskan Kinerja Karyawan.

\begin{tabular}{|c|c|c|c|c|c|c|}
\hline \multicolumn{7}{|c|}{ ANOVA $^{\mathrm{a}}$} \\
\hline \multicolumn{2}{|r|}{ Model } & $\begin{array}{l}\text { Sum of } \\
\text { Squares }\end{array}$ & $\mathrm{df}$ & $\begin{array}{l}\text { Mean } \\
\text { Square }\end{array}$ & $F$ & Sig. \\
\hline \multirow[t]{3}{*}{1} & Regression & 5.730 & 2 & 2.865 & 5.733 & $.048^{b}$ \\
\hline & Residual & 129.020 & 33 & 3.910 & & \\
\hline & Total & 134.750 & 35 & & & \\
\hline \multicolumn{7}{|c|}{ a. Dependent Variable: Kinerja Karyawan } \\
\hline \multicolumn{7}{|c|}{ b. Predictors: (Constant), Iklim Organiasi, Kepuasan Kerja } \\
\hline
\end{tabular}

Tabel 8 F- Test

Hasil Uji Anova pada Tabel 8 tersebut menunjukkan bahwa nilai $\mathrm{F}_{\text {hitung }}$ sebesar 0,733 dengan taraf signifikansi sebesar 0,488. Nilai ini kemudian dibandingkan dengan nilai $\mathrm{F}_{\text {tabel }}$ yang dihitung pada derajad bebas pembilang (df pembilang) sebesar 2 dan derajad bebas penyebut (df penyebut) sebesar 34 pada sebesar 0,05 yang 


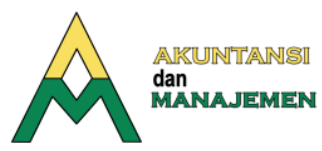

https://akuntansi.pnp.ac.id/jam

e-ISSN 2657-1080, p-ISSN 1858-3687

nilainya adalah 3,14, tampak sangat jelas bahwa nilai $F_{\text {hitung }}>F_{\text {tabel }}(5,733>4,13)$, sehingga dapat disimpulkan bahwa model yang dihasilkan adalah baik dan kinerja dapat dijelaskan secara bersama-sama oleh Iklim Organisasi dan Kepuasan Kerja, dengan demikian hipotesis ketiga terbukti bahwa ada pengaruh signifikan (nyata) antara Iklim Organisasi dan Kepuasan Kerja secara bersama-sama terhadap Kinerja Karyawan dengan menerima $\mathrm{Ha}_{3}$ dan menolak Hoз.

\section{Pembahasan}

Hasil yang diperoleh dari pengujian hipotesis pada Tabel 4. menunjukkan bahwa ada pengaruh signifikan Iklim Organisasi terhadap kinerja, hal ini ditunjukkan dengan persamaan regresi $\hat{Y}=20,006+0,217 \mathrm{X}_{1}$, nilai tersebut menunjukkan positif dan juga diperoleh nilai thitung lebih besar dari tabel $(4,762>1,69)$ atau dengan nilai signifikansi 0,000 lebih kecil dari 0,05.

Iklim Organisasi berpengaruh signifikan terhadap Kinerja Karyawan. Pengujian hipotesis yang dilakukan membuktikan bahwa ada pengaruh antara Iklim Organisasi dengan Kinerja Karyawan. Hal ini mendukung penelitian Risetiawan (2002), dan Dodi (2013), bahwa Iklim Organisasi mempunyai pengaruh nyata terhadap peningkatan Kinerja Karyawan. Iklim Organisasi merupakan ciri-ciri khas yang menggambarkan lingkungan psikologik suatu organisasi yang menunjukkan isi dari kekuatan dari pengaruh antara nilai, norma, sikap, perilaku dan perasaan dari anggota tersebut. Iklim Organisasi ini dapat mempengaruhi manusia yang bekerja di dalamnya melalui sentuhan tidak tampak mata. Umpan balik yang memberikan rangsangan untuk bekerja dengan cara yang lebih efisien dan efektif daripada sebelumnya akan menyebabkan terjadinya Kepuasan Kerja karyawan.

Nilai ry $_{1}=0,504$ yang positif menunjukkan arah hubungan kedua variabel positif dengan tingkat hubungan sedang, Sugiyono [29], yang berarti semakin tinggi Iklim Organisasi maka akan semakin tinggi kinerja di PT. Yuri Cakra Brothers, dan sebaliknya semakin rendah Iklim Organisasi maka akan rendah Kinerja Karyawan. Hasil penelitian tersebut menunjukkan bahwa hipotesis yang diajukan dalam penelitian ini dapat diterima.

Sumbangan efektif yang diberikan variabel Iklim Organisasi sebesar KP $=\mathrm{ry}_{1}{ }^{2}$ $\mathrm{x} 100 \%=0,254$ terhadap Kinerja Karyawan. Kondisi tersebut menunjukkan bahwa tingkat konsistensi variabel kinerja sebesar 25,4\% dapat diprediksi oleh variabel Iklim Organisasi, sedangkan 74,6\% ditentukan oleh faktor lain yang tidak diungkap dalam penelitian ini, yaitu: motivasi, kepuasan, dan lingkungan kerja.

Terdapat pengaruh signifikan Kepuasan Kerja terhadap Kinerja Karyawan, hal ini ditunjukkan pada Tabel 5 dengan persamaan regresi $\hat{Y}=20,475+0,197 \mathrm{X}_{2}$, nilai tersebut menunjukkan positif dan juga diperoleh nilai thitung lebih besar dari tabel $(5,024>1,69)$ atau dengan nilai signifikansi 0,000 lebih kecil dari 0,05.

Kepuasan Kerja berpengaruh signifikan terhadap Kinerja Karyawan Pengujian hipotesis yang dilakukan membuktikan bahwa ada pengaruh yang searah antara Kepuasan Kerja dengan Kinerja Karyawan. Hal ini mendukung hasil penelitiannya Husnawati (2006) kaitan Kepuasan Kerja dengan Kinerja Karyawan ditunjukkan oleh keadaan perusahaan dimana karyawan yang lebih terpuaskan cenderung lebih efektif daripada perusahaan-perusahaan dengan karyawan yang kurang terpuaskan. De Rego (2013) yang menyatakan bahwa Kepuasan Kerja antara lain mempunyai peran untuk 
mencapai produktivitas dan kualitas standar yang lebih baik, menghindari terjadinya kemungkinan membangun kekuatan kerja yang lebih stabil, serta penggunaan sumber daya manusia yang lebih efisien, maka hipotesis kedua diterima.

Nilai ry $2^{2}=0,591$ yang positif menunjukkan arah hubungan kedua variabel signifikan dengan tingkat hubungan kuat, Sugiyono [29], yang berarti semakin tinggi Kepuasan Kerja maka akan semakin tinggi kinerja di PT. Yuri Cakra Brothers, dan sebaliknya semakin rendah Kepuasan Kerja maka akan rendah kinerja di PT. Yuri Cakra Brothers. Hasil penelitian tersebut menunjukkan bahwa hipotesis yang diajukan dalam penelitian ini dapat diterima.

Sumbangan efektif yang diberikan variabel Kepuasan Kerja sebesar KP $=\mathrm{ry}_{2}{ }^{2} \mathrm{x}$ $100 \%=0,349$ terhadap kinerja. Kondisi tersebut menunjukkan bahwa tingkat konsistensi variabel kinerja sebesar 34,9\% dapat diprediksi oleh variabel Kepuasan Kerja, sedangkan $65,1 \%$ ditentukan oleh faktor lain yang tidak diungkap dalam penelitian ini, yaitu: motivasi, kepuasan dan lingkungan kerja.

Terdapat pengaruh signifikan antara Iklim Organisasi dan Kepuasan Kerja secara bersama-sama terhadap Kinerja Karyawan. Hal ini ditunjukkan pada Tabel 6 dengan persamaan regresi $\hat{\mathrm{Y}}=19,826+0,065 \mathrm{X}_{1}+0,159 \mathrm{X}_{2}$, nilai tersebut menunjukkan positif dan juga diperoleh nilai $F_{\text {hitung }}$ lebih besar dari $F_{\text {tabel }}(5,733>$ 4,13), dengan nilai signifikansi 0,048 lebih kecil dari 0,05.

Iklim Organisasi dan Kepuasan Kerja secara bersama-sama berpengaruh signifikan terhadap Kinerja Karyawan. Pengujian hipotesis yang dilakukan membuktikan bahwa ada pengaruh yang signifikan antara Iklim Organisasi dan Kepuasan Kerja secara bersama-sama terhadap Kinerja Karyawan. Dengan demikian hasil penelitian ini sama dengan penelitian Prasetyo (2010) dimana variabel Kepuasan dan Iklim Organisasi mempunyai pengaruh yang positif dan signifikan terhadap produktivitas kerja karyawan. Temuan penelitian ini mendukung penelitian Rego (2013) yang membuktikan bahwa ada pengaruh positif dan signifikan antara Kepuasan Kerja dengan Kinerja Pegawai. Temuan penelitiannya mendukung hasil penelitian ini yang menyatakan Iklim Organisasi mempunyai pengaruh positif dan signifikan terhadap produktivitas kerja karyawan (Kinerja Karyawan), maka hipotesis ketiga diterima.

Nilai Coefficient Colleration (R) yang berarti Iklim Organisasi dan Kepuasan Kerja memiliki keeratan hubungan secara bersama-sama dengan Kinerja Karyawan sebesar 0,206 artinya adalah memiliki hubungan yang cukup terletak pada letak internal koefisien 0,200 - 0,400), Sugiyono [29].

Besarnya Adjusted Rsquare sebesar 0,416 atau 41,6\% artinya bahwa variabel Iklim Organisasi dan Kepuasan Kerja dapat menjelaskan variabel Kinerja Karyawan secara linier sebesar 41,6\%. Atau ada 58,4\% yang tidak dapat dijelaskan secara linier oleh variabel Iklim Organisasi dan Kepuasan Kerja, maka Iklim Organisasi dan Kepuasan Kerja merupakan variabel yang sangat baik untuk menjelaskan Kinerja Karyawan.

Variabel yang berpengaruh dominan terhadap Kinerja Karyawan adalah variabel Kepuasan Kerja $\left(\mathrm{X}_{2}\right)$. Hal ini karena nilai koefisien regresi $\left(\mathrm{b}_{2}\right)=0,204$ dan thitung sebesar 4,762 lebih besar bila dibandingkan dengan variabel Iklim Organisasi $\left(\mathrm{X}_{1}\right)$ dengan nilai koefisien regresi $\left(\mathrm{b}_{1}\right)=0,191$ dan thitung sebesar 5,024. 


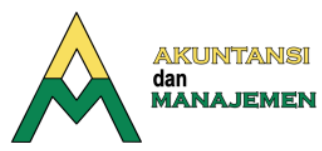

https://akuntansi.pnp.ac.id/jam

\section{Kesimpulan Dan Saran Kesimpulan}

Ada pengaruh signifikan antara iklim organisasi terhadap kinerja karyawan di PT. Yuri Cakra Brothers, hal ini ditunjukkan dengan persamaan regresi $\hat{Y}$ yang

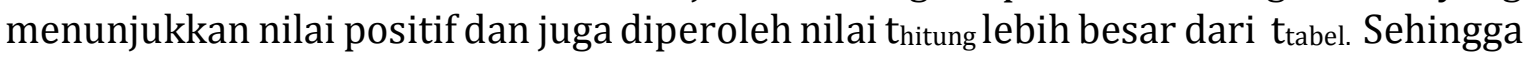
perusahaan harus benar-benar menerapkan iklim organisasi yang baik dalam meningkatkan kinerja karyawan.

Ada pengaruh signifikan antara kepuasan kerja terhadap kinerja karyawan di PT. Yuri Cakra Brothers dalam meningkatkan keinerja karyawan. dengan demikian perusahaan harus mampu meningkatkan kepusan kerja kayawan yang kemudian secara langsung meningkatkan kinerja karyawan.

Variabel iklim organisasi dan kepuasan kerja secara bersama-sama berpengaruh positif terhadap peningkatan kinerja karyawan di PT. Yuri Cakra Brothers, hal ini ditunjukkan dengan persamaan regresi, nilai tersebut menunjukkan nilai positif. Dengan demikian perusahaan harus benar-benar memperhatikan iklim organisasi dan kepuasan kerja karyawan di perusahaan agar terjadinya peningkatan kinerja karyawan.

\section{Saran}

Untuk meningkatkan kinerja para karyawan, maka karyawan di PT Yuri Cakra Brothers perlu dimotivasi dengan senantiasa meningkatkan kualitas iklim organisasi dan memberikan kompensasi yang pantas terutama kepada karyawan. Iklim organisasi dapat ditingkatkan dengan meningkatkan keakraban dan kerjasama baik antar karyawan, maupun antar karyawan dengan pimpinan.

Kepuasan kerja karyawan dalam instansi belum dapat dicapai secara maksimal karena kurangnya percaya terhadap diri pribadi karyawan dalam inovasi dan kreativitas. Oleh karena itu pimpinan PT Yuri Cakra Brothers perlu menumbuhkan rasa loyalitas dan kepercayaan diri karyawan melalui pelatihanpelatihan dan menciptakan hubungan yang baik antar karyawan.

Pimpinan PT Yuri Cakra Brothers perlu mengikut sertakan faktor-faktor yang berhubungan dengan kepuasan kerja karyawan seperti lingkungan kerja yang menyenangkan dan kompensasi dari kinerja yang mereka lakukan.

Penelitian ini hanya membahasa dampak variable iklim organisasi dan kepuasan kerja terhadap kinerja karyawan di PT. Yuri Cakra Borthers, dianjurkan untuk penelitian selanjutnya meneliti variabel lain yang berkaitan dengan kinerja kayawan.

\section{Kontribusi Penelitian}

Diharapkan artikel penelitian ini dapat menjadi referensi bagi penelitian selanjutnya dan sebagai informasi yang bermanfaat dan bahan acuan untuk meningkatkan kinerja karyawan pada PT. Yuri Cakra Brothers. 


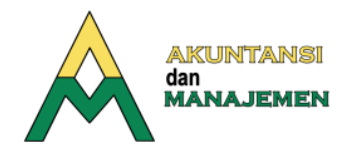

https://akuntansi.pnp.ac.id/jam

e-ISSN 2657-1080, p-ISSN 1858-3687

\section{Referensi}

[1] Argote.Linda,(2015).Organizational Learning Research, Past, Present, and Future. Journal Management Learning:42(4), 439 -446. Pitsburg: Sage Publishing.

[2] Ali, Wasif.(2016). Understanding the Concep of Job Satisfaction Measurement, Theories and its Significance in the Recent Organizational Environment A Theoretical Framework. Archeves of Business Research. 4 (1). 100-111. Varanasi Uttar Pradesh India: Faculty of Commerce Banaras Hindu University.

[3] Amstrong,Michael, \& Taylor, Stephen. (2014). Human Resources Manajement Practice. England. Kogan Limited.

[4] Al Hakim, S., dkk. 2016. Implementasi Kebijakan Remunerasi Dalam Meningkatkan Kinerja Pegawai Negeri Sipil (PNS) di Fakultas Ilmu Sosial Universitas Negeri Malang. Jurnal Ilmiah Administrasi Publik (JIAP) Vol. 2 No. 3 (2016) hal. 64-72.

[5] Azwar, Saifudin. (2014). Penyusunan Skala Psikologi. Yogyakarta: Pustaka Pelajar.

[6] Arikunto, Suharsimi. (2012). Prosedur Penelitian Suatu Opendekatan Praktis. R ineka Cipta. Jakarta.

[7] As'ad, Moch. (2011). Psikologi Industri. Liberty. Cetakan keempat. Liberty. Yogyakarta.

Baijumon, Sri. P. (2011). Manajemen Concept and Business Ethics.

Malappuram, Kerala India: University Calicut.

[8] Boxall, P., Purcell, J. \& Wright, P. (2007). The Oxford handbook of Human resource management. Purcell, J. and Kinnie, N., HRM and Business Performance, (pp. 533-551). Oxford: University press.

[9] Bhattacherjee, Anol. (2012). Social Science Research, Metheds, and Practise, (USF Tampa Library Open Access Collections. University of South Florida, 2012).

[10] Blum. (1995). Industrial Psychology and Its Social Kandarima. Hill Book Company.

[11]Dalton E,McFarland. (1974). Management: Principles and Practice. 4rd ed.The Macmillan Company.1974.

[12]De Rego, Apolinario Marcal Maia. (2013). Pengaruh Imbalan, Motivasi dan Kepuasan Kerja Terhadap Kinerja Pegawai Kejaksaan Agung dan Kejaksaan Distrik Dili.Tesis. Program Magister Manajemen, Universitas Udayana, Denpasar, Bali. 


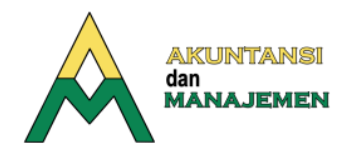

https://akuntansi.pnp.ac.id/jam

e-ISSN 2657-1080, p-ISSN 1858-3687

[13] Dodi, Ramli, dkk. (2013). “ Pengaruh Iklim Organisasi, Etos Kerja dan Disiplin Terhadap Kinerja Karyawan Serta Dampaknya Pada Kinerja PT. Arun NGL Lhokseumawe Aceh". Jurnal Manajemen. Vol.2 . No.1, November 2013.

[14] Fortuna, Y. (2016). Faktor-Faktor Yang Mempengaruhi Kepuasan Kerja Terhadap Kinerja Karyawan Pusat Penidikan Komputer Akuntansi Inter Nusa Di Jakarta. Jurnal Ekonomi, 18(3), 366-375

[15] Ghozali, Imam. 2001. Aplikasi Analisis Multivar iate Dengan Program SPSS . Semarang: Badan Peneliti Universitas Diponegoro.

[16] http://scholarcommons.usf.edu/oa textboo ks/3. (Diakses pada tanggal 26 Januari 2017).

[17] Hasibuan, Malayu S.P. 2003. Manajemen Sumber Daya Manusia . Jakarta : Bumi Aksara.

[18] Handoko, T. Hani. 2011. Manajemen Personalia dan Sumberdaya Manusia. Yogyakarta: Penerbit BPFE.

[19]Husnawati, A. (2006). Analisis Pengaruh Kualitas Kehidupan Kerja Terhadap Kinerja Karyawan Dengan Komitmen dan Kepuasan Kerja Sebagai Intervening Variabel (Studi pada PERUM Pegadaian Kanwil VI Semarang), Tesis Program Studi Magister Manajemen: Universitas Diponegoro Semarang.

[20] Hurduzeu, R. E. (2015). The Impact of Leadership on Organisational Performance. SEA Practical Application of Science, 3, 289-294.

[21] Litwin \& Stringer's, 2011, Motivation and organizational climate. Boston: Harvard University Press.

[22] Luthans, F., Avey, J. B. Avolio, B.J., Norman, S. M. \& Combs, G. M. (2007). Positive Psychological Capital: Measurement and relationship with Performance and Satisfaction. Personnel Psychology, 60, 541-572.

[23] Prasetyo, Bambang \& Lina Miftahul Jannah. 2010. Metode Peneletian Kuantitatif: Teori dan Aplikasi Jakarta: Rajagrafindo Persada

[24] Pasaribu, E., \& Indrawati, A. (2016). Pengaruh Iklim Organisasi Dan Kualitas Kehidupan Kerja Ter hadap Kinerja Pegawai Dinas Sosial Provinsi Bali. EJurnal Manajemen Universitas Udayana. 


\section{M}

https://akuntansi.pnp.ac.id/jam

e-ISSN 2657-1080, p-ISSN 1858-3687

[25] Richard L. Hughes, Robert C. Ginnett, Gordon J. Murphy. 2012. Leadership: Memperkaya Pelajaran dari Pengalaman, edisi 7. Jakarta: Salemba Humanika.

[26] Rani, I. H., \& Mayasari, M. (2016). Pengaruh Penilaian Kinerja Terhadap Kinerja Karyawan Dengan Motivasi Sebagai Variabel Moderasi. Penilain Kinerja, 3(2),1-6.

[27] Shmailan, A.S.B. (2016), The relationship between job satisfaction, job performance and employee engagement: An explorative study. Issues in Business Management and Economics, 4(1), 1-8.

[28] Subawa, I Kadek Adi dan Surya, I Bagus Ketut. 2017. Pengaruh Iklim Organisasi dan Stress Kerja terhadap Kepuasan Kerja Guru SMA 1 Gianyar. e-Jurnal Manajemen UNUD, Volume 6, Nomor 4, 2017.

[29] Sugiyono. 2010. Metode Penelitian Pendidikan Pendekatan Kuantitatif, kualitatif dan R\&D. Bandung: Alfabeta

[30] Suharsaputra, Udar, Administrasi Pendidikan. PT. Rafika Aditama, Bandung, 2013, hlm. 82

[31] Stanovich, K. E., \& Siegel, L. S. (1994). Phenotypic Performance Profile of Children with Reading Disabilities: A Regression-Based Test of the Phonological-Core Variable-Difference Model. Journal of Educational Psychology, 86, 24-53. http://dx.doi.org/10.1037/0022-0663.86.1.24

[32] Triatna, C. (2015). Perilaku Organisasi dalam Pendidikan. Bandung: Remaja Rosdakarya

[33] Wirawan. (2009). Evaluasi Kinerja Sumber Daya Manusia Teori Aplikasi dan Penelitian. Jakarta. Penerbit: Salemba Empat 